\title{
ЛЕЧЕНИЕ ОЧАГОВОЙ ДЕМИНЕРАЛИЗАЦИИ У ПОДРОСТКОВ С БРЕКЕТ-СИСТЕМОЙ
}

\section{TREATMENT OF FOCAL DEMINERALIZATION IN ADOLESCENTS WITH A BRACKET SYSTEM}

\author{
O. Gendugova \\ S. Mamresheva \\ F. Batyrbekova \\ A. Shogenov \\ T. Agnokova \\ D. Shortanova
}

Summary. The relevance of this study is that today, there is a high prevalence of dental anomalies. And for the correction of these abnormalities, non-removable orthodontic techniques are actively used. The use of these methods and poor hygiene in children and adolescents leads to the development of focal demineralization of teeth. The purpose for the study was created by 2 of a group of 85 adolescents with focal demineralization of enamel which used the method of infiltration and chemotherapy. Analyzing the results, we found that it is necessary to educate teenagers and doctors about the importance of thorough oral hygiene.

Keywords: fixed orthodontic technique, caries, prevention, transformation into enamel.
Гендугова Оксана Мухарбиевна

К.м.н., дочент, Кабардино-Балкарский государственный университет им. Х. М. Бербекова

oksistom@mail.ru

Мамрешева Снежанна Радионовна

Ассистент, Кабардино-Балкарский государственный университет им. Х.М. Бербекова

Didinag089@mail.ru

Батырбекова Фатимат Рашидовна

К.м.н., дочент, Кабардино-Балкарский государственный университет им. Х. М. Бербекова

Batyrbekovaf@mail.ru

Шогенов Анатолий Мухамедович

Ассистент, Кабардино-Балкарский государственный университет им. Х.М. Бербекова www.tolik099990@yandex.ru

Агнокова Таужан Хачимовна

К.м.н., доцент, Кабардино-Балкарский государственный университет им. Х. М. Бербекова

agnokova-t@mail.ru

Шортанова Дина Валерьевна

Ассистент, Кабардино-Балкарский государственный университет им. Х.М. Бербекова

Shortanova.dina@mail.ru

Аннотация. Актуальностью данного исследования является то, что на сегодняшний день, наблюдается высокая распространенность зубочелюстных аномалий. Для коррекции этих аномалий активно пользуются несъемными ортодонтическими техниками. Использование данных методик и плохая гигиена у детей и подростков приводит к развитию очаговой деминерализации зубов. Цель работы: Для исследования были созданы 2 группы из 85 подростков с очаговой деминерализацией эмали у которых применяли метод инфильтрации и ремотерапии. Анализируя результаты выявили, что необходимо проводить просветительскую работу среди подростков и врачей о важности тщательной гигиены полости рта.

Ключевые слова: несъемная ортодонтическая техника, кариес, профилактика, преобразования в эмали.

в этом возрасте не понимают и не осознают важность использования основных и дополнительных предметов и средств гигиены. При несоблюдении элементарных правил гигиены возникают поражения эмали с последующим образованием дефектов вокруг брекетов.[3] Чтобы оказать терапевтическую помощь приходится либо снимать дорогостоящую конструкцию, либо ждать окончания ортодонтического лечения, что может усугубить течение кариозного процесса. 
Очаговую деминерализацию можно рассматривать как осложнение ортодонтического лечения при плохой гигиене полости рта. Основное скопление зубных отложений наблюдается вокруг брекетов и пришеечной области.[4] В связи с потерей минеральных компонентов повышается опаковость и матовость этих участков. Кислоты, продуцируемые микроорганизмами налета, проникают между призмами, разрушают их, повышают проницаемость поверхностных слоев. При этом необходимо учитывать отягощающий фактор - в этом возрасте ткани зуба находятся на этапе созревания, очень уязвимы.

Зубочелюстные аномалии стоят на третьем месте в структуре стоматологических заболеваний после заболеваний пародонта и кариеса. Современная ортодонтическая техника стала очень активно применяться для коррекции зубочелюстных аномалий.[5] Она используется для нормализации формы и размеров зубных рядов, роста и развития апикальных базисов челюстей и челюстных костей, улучшения эстетики и функционирования зубочелюстной системы. Однако использование несъемной ортодонтической аппаратуры подразумевает также и риск возникновения некоторых осложнений, самым главным и распространенным из которых является кариес, несмотря на наличие в настоящее время огромного выбора средств для его профилактики и обеспечения гигиены полости рта. Решение этой проблемы зависит от своевременного применения мер профилактики кариеса, а также от выявления индивидуальных особенностей организма пациента с аномалией зубочелюстной системы, предрасполагающей к развитию кариозного процесса при использовании несъемной ортодонтической техники.

Целью нашего исследования было клиническое сравнение метода инфильтрации и ремотерапии у подростков с очами деминерализации, находящиеся на этапе ортодонтического лечения. Для проведения метода инфильтрации применяли Clinpro XT 3М, в качестве ремотерапии фторлак (Омега Дент)

Исследование проводилось визуально, обследовали 85 подростков, проходящих лечение у врача -ортодонта в СК НПЦ «С-мед», в возрасте от 10 до 16 лет. Все они планово посещают своего врача-ортодонта каждые 1-1,5 мес. Выявлено наибольшее скопление зубных отложений на верхней челюсти (63\%), чем на нижней челюсти (37\%).

Врач-ортодонт снимал дуги, дополнительные крепления (лигатуры, эластики...), направлял в кабинет терапевта, где тщательно снимались зубные отложения со всех поверхностей зубов и вокруг брекетов. Использовался Profiflex KAVO, вращающиеся щеточки и по- лировочные пасты. Поверхность зубов высушивали, окрашивали раствором метиленового синего и оценивали. Очаги деминерализации выявляли с применением увеличения, дентального бинокулярного микроскопа ZumaxMedical. Диагноз ставили на основании данных осмотра, зондирования, витального окрашивания. Всем подросткам наглядно показывали области скопления налета.

Чем дольше срок ношения несъемной ортодонтической конструкции, тем больше очагов деминерализации и больше объем поражения. При несоблюдении адекватной гигиены очаги деминерализации появлялись через 1,5-2 месяца.

Материалы и методы: для исследования были выбраны 85 детей, которых разделили на 2 группы. В первую группу входили 45 подростков все очаги деминерализации после очистки, протравливали 35\% раствором ортофосфорной кислоты в течении 5сек, это необходимо для заполнения и лучшего проникновения на всю глубину смол. Смыли кислоту, изолировали от слюны, высушили, нанесли кисточкой или брашем тонкий слой Clinpro XT 3М, полимеризовали 20 сек.

Во вторую группу были включены 40 детей, у которых после снятия зубных отложений, очаги поражения обработали Фторлаком (Омега-Дент).

После процедуры обработанные поверхности визуально выглядели гладкими, блестящими, без нарушения целостности. Следующий осмотр проводили через 1 мес. В 1группе-в виду отсутствия шероховатости, количество фиксированного налета значительно меньше, в основном межзубных промежутках. Во 2 группе - не смотря на применение ремотерапии и разъяснение важности качественной гигиены полости рта - проблема осталась и процесс деминерализации прогрессировал.

\section{Выво $\triangle \mathrm{b}$}

1. Ремотерапия не достаточна эффективна, т.к. во-первых, подростки не выполняют всех рекомендаций по уходу за полостью рта, во-вторых, при применении этого раствора, он образует на поверхности зубов крупнокристаллические образования, не проникающие вглубь деминерализации. Эта поверхностная пленка легко удаляется механически, или разрушается продуктами жизнедеятельности налета. Для получения клинического эффекта, необходимо применять многократно.

2. Clinpro XT 3М представляет собой модифицированный СИЦ, обеспечивающий выделение Са+ и фосфатов на протяжении 6 мес. Не стирается 
при чистке зубов и применяется однократно в 6 мес раз. На гладкой, полимеризованной поверхности и фиксация налета хуже. А главное - он проникает, инфильтрирует на всю глубину очаги деминерализации.

Несмотря на многочисленные методы профилактики и лечения начального кариеса, процесс рецидивирует. Необходимо проводить просветительскую работу среди подростков и врачей о важности тщательной гигиены полости рта. Это улучшит качество ортодонтического лечения, сэкономит время и деньги родителей. Надо разработать и внедрить методы профилактики и лечения начальных форм кариеса вокруг ортодонтических несъемных конструкций во время активного ортодонтического лечения, без его прерывания, не требующие многократного, инвазивного вмешательства.

\section{ЛИТЕРАТУРА}

1. Бриль Е. А. Состояние полости рта у детей с зубочелюстными аномалиями и деформациями на этапе ортодотического лечения: автореф. дис. ... доктор мед / Бриль Е. А. Наук: 14.00.21 — Омск, 2007.

2. Волкова Ю. Профилактика стоматологических заболеваний / Волкова Ю., Евгения Шапиро, Ирина Липовская. — СПб.: 000 «МЕDИ издательство», 2008.

3. Геворкян Т. В. Состояние органов и тканей полости рта при коррекции зубоальвеолярных аномалий и деформаций с использованием стоматологических КАПП: дис. ... канд. мед. наук: 14.01.14 / Геворкян Татьяна Владимировна.—М., 2014.

4. Гущина Н. В. Влияние напряженного состояния твердых тканей зуба на деминерализацию эмали при ортодонтическом лечении с использованием брекет-систем / Н. В. Гущина, В. С. Печенов, Ю. И. Няшин // Новое в стоматологии. — 2000. — № 2.

5. Шади Т.Э.Д. Характеристика частоты и распространенности осложнений, возникающих в процессе ортодонтического лечения несъемными аппаратами в городе Воронеже: дис. ... канд. мед. наук: 14.01.14 / Шади Талал Элиас Даулех.—Воронеж, 2012

() Гендугова Оксана Мухарбиевна ( oksistom@mail.ru ), Мамрешева Снежанна Радионовна ( Didinag089@mail.ru ), Батырбекова Фатимат Рашидовна ( Batyrbekovaf@mail.ru ), Шогенов Анатолий Мухамедович (www.tolik099990@yandex.ru ),

Агнокова Таужан Хачимовна ( agnokova-t@mail.ru ), Шортанова Дина Валерьевна ( Shortanova.dina@mail.ru ).

Журнал «Современная наука: актуальные проблемы теории и практики»

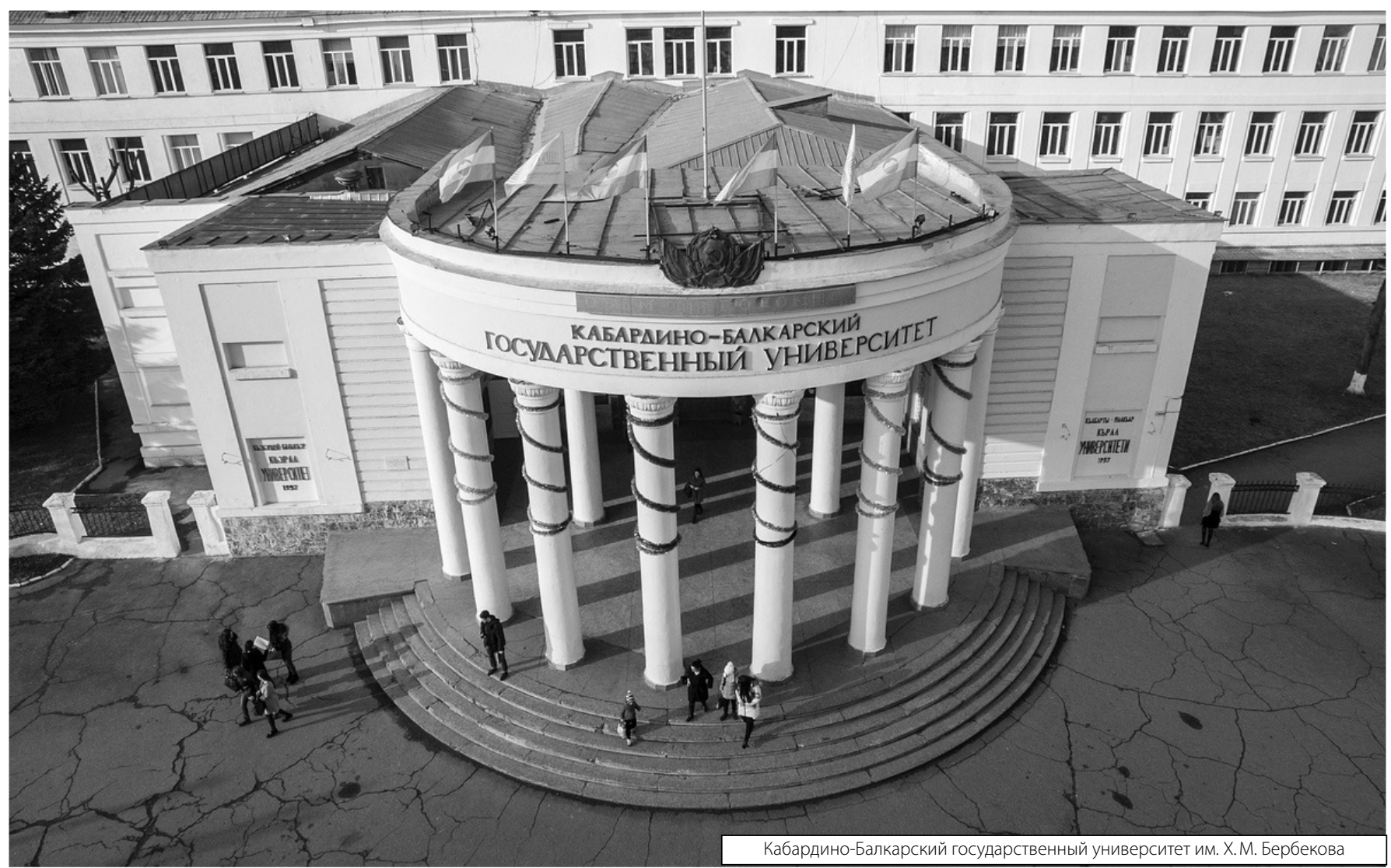

